\title{
PEMBELAJARAN BERBASIS KARAKTER DI MADRASAH IBTIDAIYAH
}

\author{
Asep Ediana Latip \\ UIN Syarif Hidayatullah Jakarta Jl. Ir. H. Juanda No. 95 Ciputat Tangerang 15412 \\ E-mail: asep_latip@yahoo.com
}

\begin{abstract}
ABSTRAK
Penelitian ini bertujuan mengetahui tingkat pemahaman, pelaksanaan dan kesulitan guru MI (madrasah ibtidaiyah) se-Jabodeta (Jakarta-Bogor-DepokTangerang) dalam pembelajaran yang berbasis karakter. Metode yang digunakan adalah survei. Sampel yang diteliti adalah 10\% dari populasi yang dipilih dengan teknik cluster sampling. Instrumen penelitian yang digunakan adalah tes dan angket. Hasil penelitian menunjukkan, ternyata $87 \%$ guru MI se-Jabodeta memahami pembelajaran berbasis karakter. Dalam hal implementasi pembelajaran berbasis karakter yang meliputi aspek rancangan karakter baik dalam persiapan maupun seleksi dan penilaian, 71\% guru MI se-Jabodeta melaksanakan pembelajaran berbasis karakter dan memiliki sarana untuk melaksanakannya. Dari total persentase tersebut, ternyata 52\% guru MI seJabodeta mengalami kesulitan untuk melaksanakan pembelajaran berbasis karakter, baik pada aspek keteladanan, pengawasan, pengukuran keberhasilan, metode penanaman karakter, proses integrasi karakter, penyusunan desain pembelajaran, buku panduan, dan identifikasi nilai karakter.
\end{abstract}

Kata Kunci : Pembelajaran, Karakter, Madrasah Ibtidaiyah

\section{ABSTRACT}

This study aims to determine the level of understanding, implementation and trouble Teachers MI (madrasah) se-Jabodeta (Jakarta-Bogor-Depok-Tangerang) in the character-based learning. The method used was a survey. Samples studied was $10 \%$ of the population are selected by cluster sampling technique. The research instrument used was a test and questionnaire. The results showed that $87 \%$ of teachers turned a Jabodeta MI-based learning to understand the character. In terms of character-based learning implementation that includes aspects of both the character design and the selection and preparation of assessment, $71 \%$ of teachers implement MI Jabodeta a character based learning and have the means to carry it out. The percentage of the total, was 52\% of teachers Jabodeta MI as difficult to implement character-based learning, both in the exemplary aspects, monitoring, measurement of success, methods of cultivation of character, the character of the integration process, preparation of instructional design, guide books, and the identification of the value of character.

Keyword: Learning, Character, and Madrasah Ibtidaiyyah 


\section{PENDAHULUAN}

Pembelajaran merupakan proses interaktif dari kegiatan belajar dan mengajar. Perspektif ini mendasari proses pembelajaran yang berakhir pada terciptanya keseimbangan kegiatan yang dilakukan oleh pelajar dan pengajar. Pengajar berperan dalam merencanakan, melaksanakan dan mengevaluasi bahan pengajaran, memilih metode pengajaran, mengolah media pengajaran, menentukan indikator hasil belajar bahkan menetapkan karakter yang diharapkan. Pembelajar berperan aktif dalam mengeksplorasi, mengelaborasi dan mengkonfirmasi setiap kegiatan yang difasilitasi oleh pengajar (Siregar dan Hartini, 2010: 13).

Konsep pembelajaran yang dibangun berdasarkan paradigma student centered, secara psikologis bermakna bahwa proses pembelajaran itu senantiasa berupaya memperhatikan tingkat perkembangan peserta didik atau developmentaly approriate practice. Peserta didik pada umumnya memiliki taraf perkembangan yang berbeda, menuntut materi berbeda pula, sehingga proses belajar itu sendiri mengandung variasi, seperti belajar keterampilan motorik, belajar konsep dan belajar sikap (Mulyasa, 2012: 129).

Dalam konteks proses, pembelajaran berlangsung dalam bentuk serangkaian kegiatan yang berjalan secara bertahap. Kegiatan pembelajaran berlangsung dari satu tahap ke tahap selanjutnya, sehingga membentuk alur yang konsisten. Langkah-langkah penyajian sistematis dalam bentuk serangkaian urutan tindakan prosedural-bertahap-berkesinambungan tersebut dinamakan prosedur pembelajaran (Madjid, 2008: 89). Prosedur pembelajaran tersebut terdapat dalam Standar Proses No. 41 tahun 2007. Prosedur tersebut dinamai dengan Rencana Pelaksanaan Pembelajaran (RPP). Urutan prosedur-bertahapberkesinambungan yang terdapat dalam RPP adalah Standar Kompetensi (SK), Kompetensi Dasar (KD), Indikator Pembelajaran, Tujuan Pembelajaran, Materi Ajar, Metode Pembelajaran, Langkah Pembelajaran (eksplorasi, elaborasi, dan konfirmasi) dan Penutup (penilaian).

Dalam konteks hasil, pembelajaran itu bersifat instructional effect dan nurturant effect. Instructional effect disebut dengan dampak yang melekat pada tujuan pembelajaran yang berupa kompetensi yang tersirat dalam Standar Kompetensi (SK) dan Kompetensi Dasar (KD). Instructional effect melekat pada semua mata pelajaran yang terdapat di setiap jalur, jenjang dan satuan pendidikan (Khan, 2010: viii). Di Indonesia, grand design-nya dibuat secara nasional dan lembaga yang berwenang dalam hal ini adalah Badan Standar Nasional Pendidikan (BSNP). Klasifikasi mata pelajaran yang terdapat di Madrasah Ibtidaiyah (MI) dikelompokan menjadi beberapa rumpun yaitu PAI, IPA, IPS, Bahasa, Sains, dan PKn (UU Sistem Pendidikan Nasional No. 20 tahun 2003). Rumpun PAI meliputi Akidah Akhlak, Sejarah Kebudayaan Islam, Al Qur'an Hadits, dan Fiqih. Pada rumpun IPS dan PKn memiliki tuntutan kompetensi yang berbasis pada penanaman karakter yang bersumber dari ajaran agama, Pancasila dan sosial kultural. Rumpun IPA, Bahasa, Sains hanya memiliki tuntutan penanaman 
kompetensi. Oleh karena itu pada rumpun mata pelajaran ini pengajar hendaknya mengkaji dan merumuskan nurturant effect-nya. Nurturant effect adalah dampak pengiring dari rumpun mata pelajaran yang tidak memiliki tuntutan langsung dalam menginternalisasi karakter terhadap peserta didik. Pendekatan pembelajaran untuk mencapai dampak pengiring tersebut dikenal dengan pembelajaran holistik atau bolistic learning (Koesoema, 2007: 263) dan pembelajaran integralistik atau integrated learning (Trianto, 2007: 13). Masingmasing konsep ini memiliki pesan yang hampir sama tentang kesemestian proses pembelajaran pada rumpun mata pelajaran umum untuk menginternalisasikan karakter terhadap peserta didik agar penanaman karakter yang dilakukan pada rumpun mata pelajaran Agama, dan PKn semakin mengkristal dan mengejawantah dalam tindakan nyata.

Karakter dalam desain induk Kemendiknas (Suyanto, 2009: 1) merupakan totalitas proses psikologis dan sosial-kultural yang dikelompokan dalam: olah hati (spiritual and emotional development), olah pikir (intellectual development), olah raga dan kinestetik (physical and kinestetic development), dan olah rasa dan karsa (affective and creativity development). Karakter yang bersumber dari olah hati antara lain: beriman dan bertakwa, jujur, amanah, adil, tertib, taat aturan, bertanggungjawab, berempati, berani mengambil risiko, pantang menyerah, rela berkorban dan berjiwa patriotik. Karakter yang bersumber dari olah pikir antara lain: cerdas, kritis, kreatif, inovatif, ingin tahu, produktif, berorientasi pada ilmu pengetahuan dan teknologi (Iptek) dan reflektif. Karakter yang bersumber dari olah raga/kinestetika antara lain: bersih, sehat, sportif, tangguh, andal, berdaya tahan, bersahabat, kooperatif, determinatif, kompetitif, ceria dan gigih. Karakter yang bersumber dari olah rasa dan karsa antara lain: kemanusiaan, saling menghargai, gotong royong, kebersamaan, ramah, hormat, toleran, nasionalis, peduli, kosmopolit (mendunia), mengutamakan kepentingan umum, cinta tanah air (patriotis), bangga menggunakan bahasa dan produk Indonesia, dinamis, kerja keras dan beretos kerja.

Untuk memenuhi sumber daya manusia berkarakter tersebut, pendidikan memiliki peran yang sangat penting. Hal ini sesuai dengan UU No 20 Tahun 2003 Tentang Sistem Pendidikan Nasional pada Pasal 3, yang menyebutkan bahwa pendidikan nasional berfungsi mengembangkan kemampuan dan membentuk karakter serta peradaban bangsa yang bermartabat dalam rangka mencerdaskan kehidupan bangsa. Pendidikan nasional bertujuan untuk berkembangnya potensi peserta didik agar menjadi manusia yang beriman dan bertakwa kepada Tuhan Yang Maha Esa, berakhlak mulia, sehat, berilmu, cakap, kreatif, mandiri, dan menjadi warga negara yang demokratis serta bertanggung jawab.

Berdasarkan fungsi dan tujuan pendidikan nasional, pendidikan di setiap jenjang, termasuk pendidikan dasar (MI/SD) harus diselenggarakan secara sistematis. Hal tersebut berkaitan dengan pembentukan karakter peserta didik sehingga mampu bersaing, beretika, bermoral, sopan santun dan berinteraksi 
dengan masyarakat. Berdasarkan penelitian yang diterbitkan oleh Character Education Partnership, ternyata kesuksesan seseorang tidak ditentukan semata-mata oleh pengetahuan dan kemampuan teknis (hard skill) saja, tetapi lebih oleh kemampuan mengelola diri dan orang lain (soft skill). Penelitian ini mengungkapkan, kesuksesan hanya ditentukan sekitar 20\% oleh hard skill dan sisanya $80 \%$ oleh soft skill. Bahkan orang-orang tersukses di dunia bisa berhasil dikarenakan lebih banyak didukung kemampuan soft skill daripada hard skill. Hal ini mengisyaratkan bahwa mutu pendidikan karakter peserta didik sangat penting untuk ditingkatkan (Suyanto, 2009: 1).

Dalam proses pembelajaran berbasis karakter meniscayakan pola pembinaan karakter secara komprehensif pada semua bidang studi yang diajarkan. Selama ini pola pendidikan karakter dalam pembelajaran masih parsial yaitu melalui pola bidang studi tertentu, misalnya pada Bidang Studi Pendidikan Agama Islam (PAI), Pendidikan Kewarganegaraan (PKn) dan Pendidikan Ilmu Sosial (IPS) dalam jumlah jam yang sedikit dibandingkan dengan bidang studi yang tidak memiliki beban pembinaan karakter. Oleh karena itu upaya integrasi ke dalam semua bidang studi merupakan salah satu jawaban untuk melengkapi optimalisasi pendidikan karakter dalam proses pembelajaran berbasis karakter di sekolah. Apabila dilihat dari standar nasional pendidikan yang menjadi acuan pengembangan kurikulum (KTSP), implementasi pembelajaran dan penilaian di sekolah, sebenarnya tujuan pendidikan di MI dapat dicapai dengan baik. Pembinaan karakter juga termasuk dalam materi yang harus diajarkan dan dikuasai serta direalisasikan oleh peserta didik dalam kehidupan sehari-hari. Pendidikan karakter di sekolah, selama ini baru menyentuh pada tingkatan pengenalan norma atau nilai-nilai, belum pada tingkatan internalisasi dan tindakan nyata dalam kehidupan sehari-hari.

Langkah integrasi pembinaan pendidikan karakter pada setiap bidang studi yang diajarkan di sekolah menuntut adanya kompetensi para guru di samping adanya dukungan bahan ajar yang harus diorientasikan pada penanaman karakter. Problem peningkatan mutu guru selama ini masih merupakan salah satu problem utama di samping problem lain seperti fasilitas, biaya dan relevansi, serta proses supervisi dari kepala sekolah bagi tercapainya keberhasilan implementasi pendidikan karakter karena guru adalah role model secara ke'ilmuan ataupun ke'amalan.

Guru merupakan driver bagi roda pendidikan termasuk proses pembelajaran. Pembelajaran akan berjalan efektif ketika guru merencanakan dengan efektif. Pendidikan karakter yang diharapkan terintegrasi dalam proses pembelajaran juga harus direncanakan secara terintegrasi agar proses pembelajaran berjalan efektif sehingga tujuan pembelajaran tercapai secara optimal baik tujuan pencapaian kompetensi maupun tujuan pembinaan karakter (Zubaedi, 2011: 14). Kemampuan merencanakan secara efektif proses pembelajaran integrasi atau comprehensif learning merupakan salah satu indikasi yang menunjukkan kualitas pencapaian tujuan pembelajaran dan pembinaan 
karakter. Secara teoretik guru harus memperhatikan dampak positif proses pembelajaran yang komprehensif karena sangat besar manfaatnya untuk jangka panjang. Kepemilikan proses pembelajaran komprehensif ini bisa diperoleh melalui proses pendidikan, pelatihan dan/atau workshop pendididkan karakter. Proses pembelajaran berbasis karakter akan berlangsung efektif ketika di dalamnya terdapat perencanaan pembelajaran yang memuat prosedur pembelajaran, kegiatan pembelajaran sebagai wujud dari perencanaan dan penilaian sebagai tolok ukur ketercapaian tujuan pembelajaran berbasis karakter. Oleh karena itu perlu dilakukan penelitian tentang grand design pendidikan karakter di sekolah, khususnya MI agar dalam prosesnya mampu dilaksanakan oleh para guru secara komprehensif pada setiap bidang studi yang diajarkan guna menciptakan insan-insan berkarater yang sesuai dengan harapan.

Penelitian ini bertujuan mengungkap pemahaman guru tentang pembelajaran berbasis karakter di MI, mengkaji dan memecahkan sejumlah kesulitan yang dialami oleh guru dalam pelaksanaan pembelajarannya. Populasi penelitian ini adalah para guru yang mengajar di MI yang berasal dari wilayah Jakarta, Bogor, Depok dan Tanggerang yang sedang mengikuti Program Peningkatan Kualifikasi Guru (PPKG) di UIN Syarif Hidayatullah Jakarta. Metode penelitian yang digunakan adalah metode survei. Penentuan metode ini didasarkan pada tujuan penelitian yakni bermaksud membuktikan keterlaksanaan pembelajaran berbasis karakter di Madrasah Ibtidaiyah (MI). Metode ini pun dapat menjadi cara yang ilmiah untuk memahami, memecahkan dan mengantisipasi masalah penelitian ini. Memahami artinya memperjelas informasi tentang pemahaman/pengetahuan guru MI terhadap pembelajaran berbasis karakter. Memecahkan masalah maksudnya adalah meminimalisir kesulitankesulitan guru dalam pelaksanaan pembelajaran berbasis karakter di MI. Mengantisipasi masalah maksudnya mengupayakan kualitas keterlaksanaan pembelajaran berbasis karakter di MI.

Madrasah yang terdapat di empat wilayah tersebut sebanyak 273. di Jakarta Selatan terdapat 95 MI, Kabupaten Bogor 60 MI, Depok 68 MI dan kota Tangerang 50 MI. Dari 273 MI yang tersebar di wilayah Jabodeta tersebut terdapat 412 guru MI yang mengikuti Program Peningkatan Kualifikasi (PPKG) di UIN Syarif Hidayatullah Jakarta. Dari 412 guru MI terhitung yang berasal dari Jakarta Selatan adalah 133, Kabupaten Bogor 163, Depok 70 dan Kota Tangerang 46 guru MI. Dari populasi tersebut (412) diambil sampel sebanyak 10\%, yaitu 41 guru MI, dengan rincian guru yang berasal dari Jakarta Selatan 13 orang, Kabupaten Bogor 16, Depok 7 dan dari Kota Tangerang sebanyak 5 guru MI. Teknik sampling yang digunakan adalah non probability sampling; yaitu teknik pengambilan sampel yang tidak memberikan peluang yang sama bagi setiap unsur (anggota) populasi untuk dipilih menjadi anggota sampel kemudian dilanjutkan dengan cluster random sampling berdasarkan distribusi guru yang berasal dari berbagai wilayah yang ada di Jabodeta (www.mapenda.go.id). 
Teknik pengumpulan data yang digunakan adalah kuesioner dan test. Kuesioner merupakan pengumpulan data yang dilakukan dengan cara memberi seperangkat pertanyaan atau pernyataan tertulis kepada responden untuk dijawabnya (Sugiyono: 2012: 199-200). Teknik kuesioner dipilih dalam penelitian ini, karena variabel penelitian yang akan diukur sudah pasti, yaitu pembelajaran berbasis karakter. Teknik ini juga merupakan teknik yang efektif untuk mengukur tujuan penelitian ini dari responden yang sudah ditetapkan yaitu menjaring informasi mengenai pelaksanaan dan kesulitan pelaksanaan pembelajaran berbasis karakter di MI. Untuk mengukur pemahaman menggunakan teknik tes. Teknik test menggunakan pilihan benar/salah, tetapi supaya menghindari kesan di tes dan mungkin menyebabkan stress pada responden sehingga mendorong sikap menyontek jawaban maka diganti menjadi setuju/tidak setuju dari setiap pernyataan yang diajukan. Kuisioner ini disebarkan selama bulan Mei - Juni 2012.

Analisis data dilakukan terhadap data berdasarkan variabel pembelajaran berbasis karakter dan kelompok responden yakni para guru MI yang mengikuti Program Peningkatan Kualifikasi Guru (PPKG). Caranya dengan mentabulasi data berdasarkan variabel pembelajaran berbasis karakter dari seluruh responden para guru MI Program Peningkatan Kualifikasi Guru (PPKG), menyajikan data pembelajaran berbasis karakter dan melakukan perhitungan untuk menjawab rumusan masalah berkenaan dengan pemahaman guru, pelaksanaan dan kesulitan guru terhadap pembelajaran berbasis karakter. Analisis data berikutnya dilakukan dengan teknik statistik deskriptif. Teknik ini digunakan karena penelitian ini diorientasikan untuk mendeskripsikan data sampel dan tidak diorientasikan untuk membuat kesimpulan yang berlaku untuk populasi di mana sampel diambil, yaitu untuk mendapatkan gambaran distribusi subyek penelitian berdasarkan wilayah, jumlah subyek yang telah menerapkan pembelajaran berbasis karakter, dan distribusi kesulitan penerapan pembelajaran berbasis karakter.

Variabel penelitian pelaksanaan pembelajaran berbasis karakter ini dikembangkan menjadi tiga variabel yang meliputi pemahaman, pelaksanaan dan kesulitan guru MI dalam pelaksanaan pembelajaran berbasis karakter. Pada instrumen tes pemahaman diajukan 15 pertanyaan tentang konfigurasi dilaksanakannya pembelajaran berbasis karakter di sekolah, nilai karakter pada setiap mata pelajaran dan upaya guru dalam menerapkan pembelajaran berbasis karakter.

\section{PEMBAHASAN}

Hasil penelitian menunjukkan bahwa 87.6\% guru MI se-Jabodeta memahami konsep penerapan pembelajaran berbasis karakter dengan rata-rata nilai 87. Nilai ini menggambarkan bahwa para guru MI memahami dengan baik konsep pembelajaran berbasis karakter. Hal ini merujuk pada rumusan kriteria keberhasilan implementasi pendidikan karakter yang dikembangkan oleh 
Mulyasa (2012: 15) bahwa keberhasilan implementasi pendidikan karakter di sekolah dapat dilihat dalam jangka pendek, jangka menengah dan jangka panjang. Untuk kriteria jangka pendek, sekurang-kurangnya 85\% isi dan prinsipprinsip pendidikan karkater dapat dipahami, diterima dan diterapkan oleh para peserta didik dan guru. Kriteria jangka menengah cirinya adalah, para peserta didik menjadi insan yang berkarakter, kreatif dan mampu menghadapi berbagai permasalahan yang dihadapinya. Kriteria jangka panjang yaitu tumbuhnya karakter kemandirian dan berkurangnya ketergantungan di kalangan warga sekolah, bersifat adaptif dan proaktif serta memiliki jiwa kewirausahaan yang tinggi (ulet, inovatif dan berani dalam mengambil risiko).

Untuk variabel pelaksanaaan pembelajaran berbasis karakter dikembangkan menjadi tiga dimensi penelitian yaitu desain pelaksanaan pembelajaran berbasis karakter, pendekatan pembelajaran berbasis karakter dan penilaian pembelajaran berbasis karakter. Ketiga dimensi penelitian ini disusun ke dalam bentuk rating scale berupa; selalu, sering, kadang dan tidak pernah yang masing-masing skala bernilai 4, 3, 2, dan 1 yang disusun ke dalam 50 pernyataan. Penelitian ini menunjukkan bahwa $71 \%$ guru MI se-Jabodeta telah melaksanakan pembelajaran berbasis karakter di sekolahnya masing-masing yang meliputi pemenuhan perangkat pembelajaran berbasis karakter yang berupa desain, pendekatan dan penilaian pembelajaran berbasis karakter.

Seperti variabel pelaksanaan pembelajaran berbasis karakter, untuk variabel faktor-faktor kesulitan guru dalam melaksanaan pembelajaran berbasis karakter dikembangkan instrumen penelitian dalam bentuk rating scale. Faktorfaktor kesulitan guru yang disajikan dalam penelitian ini berkenaan dengan aspek teladan guru, monitoring penanaman karakter, penilaian hasil belajar karakter, metode penanaman karakter, proses integrasi karakter pada mata pelajaran, penyusunan desain karakter, buku panduan dan identifikasi nilai karakter. Hasilnya menunjukkan bahwa 52\% guru MI se-Jabodeta banyak menemukan kesulitan dalam penerapan pembelajaran berbasis karakter.

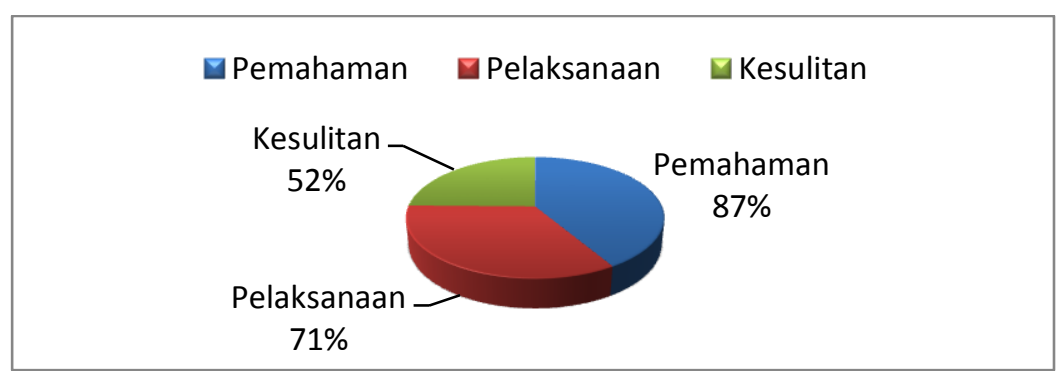

Pemahaman guru MI terhadap pembelajaran berbasis karakter berdasarkan distribusi wilayah adalah 90\% guru MI yang berasal dari Bogor, 93\% guru MI yang berasal dari Jakarta Selatan, $85 \%$ yang berasal dari Kota Tangerang dan $81 \%$ yang berasal dari Depok telah memahami penerapan pembelajaran berbasis karakter. 


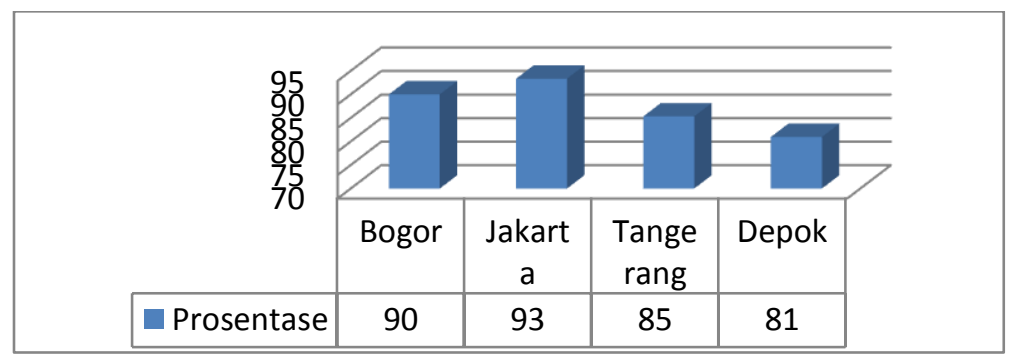

Komponen yang dijadikan standar utama pemahaman guru terhadap pembelajaran berbasis karakter dalam penelitian ini terdiri dari tiga aspek yaitu konfigurasi pilar karakter, nilai-nilai karakter dalam setiap mata pelajaran dan upaya pembelajaran berbasis karakter. Konfigurasi pilar pembelajaran berbasis karakter menunjukkan bahwa 87\% guru MI se-Jabodeta mengetahui konfigurasi karakter yang menjadi landasan pelaksanaan pembelajaran berbasis karakter di sekolah yaitu karakter yang bersumber pada olah hati, olah pikir, olah raga, dan olah rasa. 90.2\% meyakini bahwa secara potensial konfigurasi karakter tersebut dapat diinternalisasikan terhadap peserta didik di sekolah karena secara kondrati pilar karakater tersebut tidak bertentangan dengan naluri potensial pada setiap peserta didik sebagai individu.

Nilai-nilai karakter dalam setiap mata pelajaran diketahui bahwa $95.5 \%$ guru MI se-Jabodeta memahami bahwa setiap mata pelajaran memiliki tujuan penerapan karakter pada setiap mata pelajaran yang terintegrasi pada setiap tujuan mata pelajaran yang sudah dirumuskan berdasarkan standar isi yang terangkum dalam standar kompetensi dan kompetensi dasar. Seperti yang dijelaskan oleh Gunansyah (2010: 2-5) bahwa Setiap mata pelajaran pada prinsipnya memiliki bahan ajar (instructional materials) berdimensi pengetahuan, keterampilan dan sikap/nilai. Depdiknas (2006) mengartikan bahan ajar atau materi pembelajaran secara garis besar terdiri dari pengetahuan, keterampilan, dan sikap yang harus dipelajari siswa dalam rangka mencapai standar kompetensi yang telah ditentukan. Mata pelajaran apapun termasuk yang ada di SD/MI sarat dengan kandungan dimensi penanaman dan pembinaan sikap/nilai yang melekat dalam setiap aktivitas pembelajaran. Sedangkan pada upaya melakukan proses integrasi nilai karakter pada setiap mata pelajaran yang tidak mengandung instructional effect atau dampak langsung penanaman nilai karakter, dari penelitian ini diketahui bahwa terdapat $82 \%$ guru MI se-Jabodeta yang memahami proses integrasi nilai karakter pada setiap mata pelajaran yang dihubungkan dengan kehidupan sehari-hari di lingkungan masyarakat sekitar. Ketika guru MI diajukan pernyataan berkenaan dengan tingkat kepentingan dari pelaksanaan pembelajaran berbasis karakter, dari penelitian ini diketahui bahwa $65.9 \%$ guru MI merasa penting diterapkannya pembelajaran berbasis karakter pada setiap mata pelajaran di sekolah dengan alasan terbatasnya perangkat terpadu dalam mewujudkan nilai-nilai karakter. Seperti yang dijelaskan dalam desain Induk Pembangunan Karakter Bangsa (Mulyasa: 2012: 229-231) bahwa penanaman 
nilai-nilai Pancasila sebagai wahana dan sarana membangun karakter bangsa, meningkatkan komitmen terhadap NKRI, serta menumbuhkembangkan etika kehidupan berbangsa bagi seluruh rakyat Indonesia belum optimal. Oleh karena itu, perwujudan nilai-nilai esensi Pancasila pada semua lapisan masyarakat Indonesia perlu didukung perangkat kebijakan terpadu.

Esensi utama dalam pelaksanaan pembelajaran berbasis karakter adalah tertanamnya nilai karakter baik yang bersumber dari sosial kultural atau sosial ideologis kebangsaan. Penelitian ini menunjukkan bahwa 90\% guru MI se Jabodeta memahami tentang karakter yang dikembangkan berbasis pada semangat kebangsaan. Dalam desain Induk Pembangunan Karakter Bangsa (Mulyasa: 2012: 232) dijelaskan bahwa pembangunan karakter bangsa bertujuan untuk membina dan mengembangkan karakter warga negara sehingga mampu mewujudkan masyarakat yang berkebutuhan yang Maha Esa, berkemanusiaan yang adil dan beradab, berjiwa persatuan Indonesia, berjiwa kerakyatan yang dipimpin oleh hikmat kebijaksanaan dalam permusyawaratan perwakilan, serta berkeadilan sosial bagi seluruh rakyat Indonesia. Sedangkan berkenaan dengan pengolahan nilai karakter pada setiap mata pelajaran, penelitian ini menunjukkan bahwa $82 \%$ guru MI se Jabodeta memahami bahwa karakter yang terdapat dalam setiap mata pelajaran diorganisasikan secara sistematis dalam setiap pembelajaran sehingga proses pembelajaran dilakukan untuk menanamkan nilai-nilai karakter secara integrated.

Berhubungan dengan upaya pengelolaan pembelajaran berbasis karakter, diketahui bahwa 97\% guru MI se-Jabodeta memahami bahwa pembelajaran berbasis karakter dilaksanakan dengan mengembangkan pembelajaran bermakna (meaningfull learning). Prosesnya disesuaikan dengan pengalaman nyata atau pembelajaran yang berguna bagi kehidupan sehari-sehari. Sebanyak 90\% guru juga memahami bahwa pembelajaran berbasis karakter dilaksanakan melalui proses pembudayaan dan pemberdayaan semua komponen perangkat pembelajaran seperti guru, peserta didik serta ketersediaan sarana dan prasarana. Sebanyak 87\% guru MI se-Jabodeta memahami bahwa pembelajaran karakter secara praktis dapat dilakukan melalui proses belajar yang aktif seperti diskusi, kegiatan kelompok dan berbasis pemecahan masalah. Berkenaan dengan proses integrasi nilai karakter dalam mata pelajaran, diketahui bahwa 95\% guru MI seJabodeta memahami proses integrasi nilai karakter pada setiap mata pelajaran dilakukan secara langsung melalui proses identifikasi setiap standar kompetensi yang terdapat dalam setiap mata pelajaran kemudian dirumuskan nilai-nilai karakter yang sesuai dengan instructional effect. Adapun untuk mengukur ketercapaian internalisasi karakter kepada peserta didik, diketahui bahwa $97 \%$ guru memiliki pemahaman dan sepakat bahwa keberhasilan penerapan karakter dapat ditentukan dengan proses penilaian yang sistematis dan sesuai dengan tujuan pembelajaran pada setiap mata pelajaran. Untuk pengelolaan materi baik mulai dari perumusan nilai karakter, langkah-langkah pembelajaran maupun penilaian pembelajaran berbasis karakter, diketahui bahwa 92\% guru memahami 
bahwa pembelajaran karakter dapat efektif dilaksanakan apabila terlebih dahulu didesain di dalam RPP.

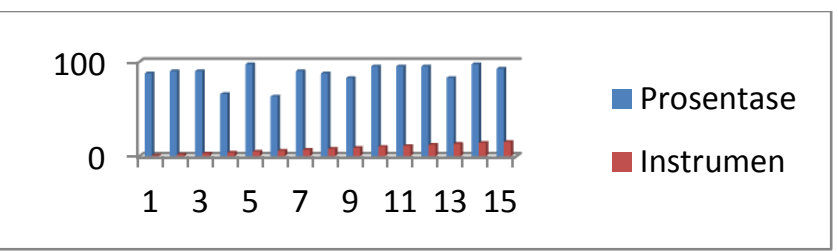

Berdasarkan distribusi guru MI yang tersebar dari wilayah Jabodeta diketahui bahwa 77\% guru MI Bogor dan Jakarta, 69\% guru MI Depok, dan $62 \%$ guru MI Tangerang telah melaksanakan pembelajaran berbasis karakter.

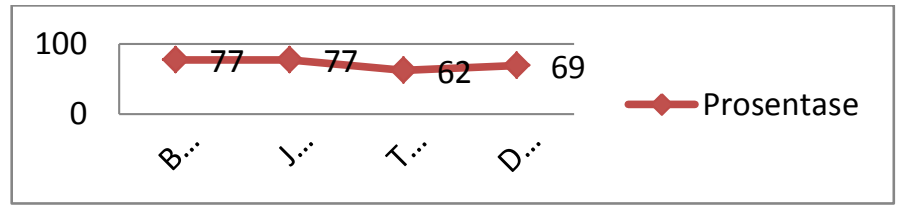

Apabila dilihat berdasarkan presentasi Skala Likert dengan memberikan predikat sering, selalu, kadang-kadang dan tidak pernah diperoleh hasil 33\% selalu, 33\% sering, 29\% kadang-kadang dan 5\% tidak pernah melakukan proses pembelajaran berbasis karakter di wilayah Jabodeta.

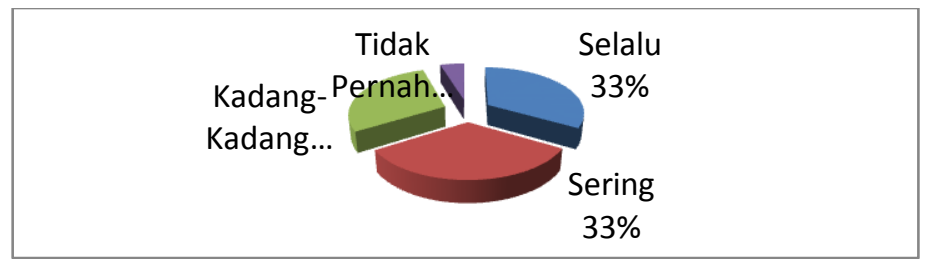

Untuk mengidentifikasi guru MI yang telah melaksanakan pembelajaran berbasis karakter dikelompokan ke dalam empat kegiatan pelaksanaan pembelajaran dengan merujuk pada teori yang dikembangkan oleh Gagne (Zubaedi, 2012: 191) juga berdasarkan pada Permendiknas No 22 tahun 2007 tentang Standar Proses yaitu kegiatan mendesain pembelajaran, kegiatan pendahuluan, kegiatan inti dan kegiatan penilaian.

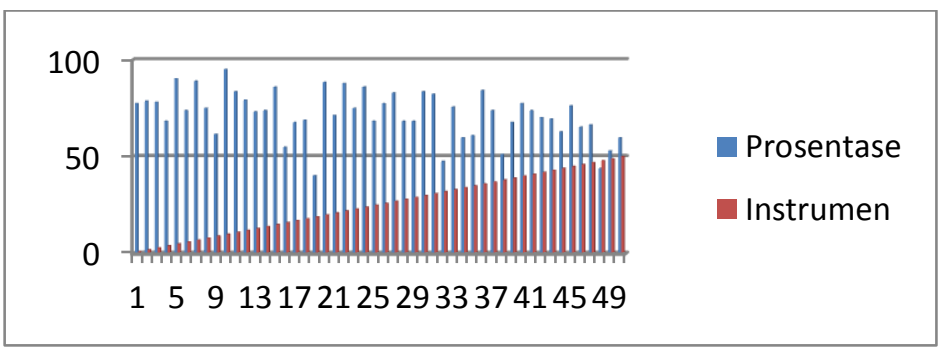


Komponen desain pembelajaran berbasis karakter minimal terdiri atas rumusan indikator karakter, integrasi karakter, batasan karakter dan prosedur pembelajaran berbasis karakter. Rumusan karakter memuat nilai-nilai karakter yang terdapat dalam mata pelajaran yang bersifat instructional effect yaitu mata pelajaran yang misi utamanya penanaman karakter seperti PAI dan PKn, guru dapat dengan mudah merumuskan karakter yang bersumber langsung dari Standar Kelulusan Mata Pelajaran (SKLMP), Standar Kompetensi dan Kompetensi Dasar (SK-KD). Semua kegiatan ini telah dilakukan oleh 68\% guru MI di wilayah Jabodeta. Merumuskan indikator karakter juga dapat dilakukan dengan bersumber pada rumusan indikator pembelajaran, agar nilai karakter yang terdapat dalam indikator pembelajaran akan lebih spesifik dan operasional untuk dikaji oleh para pendidik. Hal ini telah dilakukan oleh $75 \%$ guru MI di wilayah Jabodeta. Komponen integrasi karakter berisi rumusan nilai karakter yang terdapat dalam mata pelajaran umum bersifat nurturant instruction. Cara perumusannya yaitu dengan mengkaji pengalaman-pengalaman bernilai karakter yang terdapat dalam mata pelajaran umum untuk diterapkan oleh peserta didik dalam kehidupan sehari-hari. Hasilnya 73\% guru MI se-Jabodeta telah merumuskan nilai karakter secara terintegrasi dalam mata pelajaran.

Komponen batasan karakter berisi pemilihan dan penentuan nilai karakter dengan mempertimbangkan kemampuan peserta didik, tingkat kesulitan dan kemudahan nilai karakter tersebut ketika diterapkan kepada peserta didik. Kegiatan pembatasan karakter telah dilakukan oleh 65\% guru MI di wilayah Jabodeta. Komponen prosedur pembelajaran berbasis karakter berisi langkahlangkah kegiatan pembelajaran yang mengoperasikan semua komponen pembelajaran yaitu melalui prosedur pendahuluan, inti dan penutup, termasuk dalam prosedur tersebut penggunaan media, sumber dan pendekatan pembelajaran yang harus dilakukan selama proses pembelajaran. Prosedur ini telah dilakukan oleh $77 \%$ guru MI se-Jabodeta.

Kegiatan pendahuluan merupakan kegiatan guru untuk memberikan motivasi, menjelaskan tujuan pembelajaran, membiasakan kegiatan keagamaan, mengecek kesiapan belajar peserta didik, apersepsi dan menjelaskan karakter yang diharapkan. Dari sejumlah kegiatan pendahuluan, ternyata $77 \%$ guru MI memulai pembelajaran dengan memberikan motivasi seperti melakukan kegiatan ice breaking. Sebelum memulai kegiatan pembelajaran, ternyata 89\% guru MI berdo'a sebelum belajar dengan harapan tertanam nilai karakter religius pada peserta didik. Pengecekan kesiapan belajar peserta didik senantiasa dilakukan supaya peserta didik siap secara fisik dan mental dalam belajar sehingga hasil belajar tercapai dengan optimal dan ternyata $77 \%$ guru MI telah melaksanakannya.

Kegiatan apersepi dalam kegiatan pendahuluan dilakukan dengan dua teknik yaitu menjelaskan hubungan pembelajaran dengan kehidupan seharisehari dan mengajukan pertanyaan kepada peserta didik tentang pengetahuan awal dan pengalaman awal tentang materi yang akan diajarkan disebut dengan 
meaningfull learning. Teknik apersepsi dengan penjelasan hubungan tujuan pembelajaran dengan kehidupan sehari-hari dilakukan oleh $79 \%$ guru MI seJabodeta, sedangkan teknik pertanyaan dalam apersepi dilakukan oleh $83 \%$ guru MI se-Jabodeta. Dalam pembelajaran berbasis karakter, tujuan pembelajaran tidak hanya berupa penjelasan tujuan instruksional tetapi juga berupa pemberian penjelasan nilai karakter yang terdapat dalam standar kompetensi dan kompetensi dasar. Terdapat 68\% guru MI se-Jabodeta menyatakan bahwa mereka menjelaskan nilai karakter yang diharapkan pada setiap standar kompetensi dan kompetensi dasar setiap kali memulai kegiatan pembelajaran.

Kegiatan inti pembelajaran berbasis karakter terdiri atas kegiatan eksplorasi, elaborasi dan konfirmasi. Dalam kegiatan eksplorasi guru dapat menggunakan pendekatan inculcation value. Dalam kegiatan elaborasi guru dapat menggunakan pendekatan value clarification, moral cognitive dan action learning. Dalam kegiatan konfirmasi guru dapat menggunakan pendekatan union. Proses penerapan pendekatan inculcation value atau pendekatan penanaman nilai adalah suatu pendekatan yang memberi penekanan pada pananaman nilai-nilai sosial dalam diri peserta didik. Konsep ini didasarkan pada asumsi yang dikembangkan oleh J. Raven (Zubaedi, 2011: 209-2010) bahwa social values are set of society attitude considered as a truth and it is become the standard for people to act in order to achieve democratic and harmonious life. Artinya, nilai-nilai sosial merupakan seperangkat sikap individu yang dihargai sebagai suatu kebenaran dan dijadikan standar bertingkah laku guna memperoleh kehidupan masyarakat yang demokratis dan harmonis.

Inculcation value disebut oleh Kesuma (2011: 117) sebagai model reflektif. Model reflektif dalam pembelajaran berbasis karakter dapat dilakukan secara efektif ketika pelaksanaannya didasarkan pada berberapa prinsip pembelajaran reflektif yang diidentifikasi oleh Kesuma (2011: 120) sebagai prinsip kasih sayang, prinsip keteladanan dan prinsip perkembangan peserta didik yang dapat menggunakan teknik penanaman nilai karakter melalui diskusi, cerita dan kisah. Pada aspek penanaman nilai karakter dengan prinsip kasih sayang, diketahui bahwa proses inculcation value dalam proses pembelajaran mayoritas $(90 \%)$ guru MI se-Jabodeta menerapkan proses penanaman nilai dengan menerapkan prinsip kasih sayang kepada peserta didik. Prinsip kasih sayang artinya kegiatan pembelajaran hendaknya didasarkan pada proses pembelajaran yang akan melahirkan karater anak yang percaya diri dan mandiri serta dibangun dalam suasana belajar yang nyaman dan aman atau disebut oleh Erick Erickson (Jamaris, 2010: 41) suasana belajar yang akan melahirkan trust. Proses inculcation atau reflektif dalam pembelajaran ini membutuhkan kerja keras dan wawasan guru karena proses pembelajaran reflektif diistilahkan oleh Khan (2010: viii) sebagai nurturant effect yang dilakukan melalui pengaitan materi-materi yang dibahas dalam pembelajaran dengan makna di belakang materi tersebut. Dengan kata lain, dalam proses pembelajaran ini guru menjelaskan keterkaitan materi tersebut dalam nilai kehidupan. 
Proses inculcation value dapat dilakukan dengan proses pembelajaran melalui diskusi dan ternyata 55\% guru MI se-Jabodeta memilih kegiatan tersebut. Kegiatan diskusi mendorong terciptanya karakter saling menghargai, kerjasama dalam menyelesaikan masalah dan saling membantu. Proses inculcation value melalui cerita menjadi pilihan utama guru MI se-Jabodeta (68\%). Materi cerita dapat berkenaan dengan peristiwa aktual atau pengalaman dari peserta didik tentang karakter tertentu yang telah dirumuskan atau cerita dari contoh-contoh prilaku orang yang memiliki karakter yang telah dirumuskan. Proses inculcation value juga dapat dilakukan dengan melalui penjelasan kisah/sejarah perjuangan, pengorbanan, kepemimpinan dan kejujuran. Proses ini dilakukan oleh 69\% guru MI se-Jabodeta.

Penerapan pendekatan value clarification atau pembelajaran klarifikasi nilai merujuk pada penjelasan Zubaedi (2011: 208) memberi penekanan pada usaha membantu peserta didik dalam mengkaji perasaan dan perbuatannya sendiri untuk meningkatkan kesadaran mereka tentang nilai-nilai mereka sendiri. Tujuan dari pendekatan ini adalah 1) membantu peserta didik untuk menyadari dan mengidentifikasi nilai-nilai mereka sendiri serta nilai-nilai orang lain, 2) membantu peserta didik, supaya mereka mampu berkomunikasi secara terbuka dan jujur dengan orang lain yang berhubungan dengan nilai-nilainya sendiri, 3) membantu peserta didik, supaya mereka mampu menggunakan secara bersamasama kemampuan berpikir rasional dan kesadaran emosional, untuk memahami perasaan, nilai-nilai dan pola tingkah laku mereka sendiri. Untuk memperoleh tujuan klarifikasi nilai tersebut, dalam proses pembelajaran berbasis karakter dapat dilakukan dengan pemberian penghargaan (reward) dan hukuman (punishment). Untuk penerapan pendekatan value clarification melalui proses pemberian penghargaan atau reward ini elah dilaksanakan oleh 95\% guru MI seJabodeta. Bentuk penghargaan yang dipilih oleh 76\% guru MI se-Jabodeta yaitu dengan memberikan penghargaan berupa verbalistik/lisan seperti pujian atau nonverbalistik seperti tepuk tangan, pemberian nilai dan hadiah.

Penerapan pendekatan value clarification melalui hukuman atau punishment dilakukan oleh 88\% guru MI se-Jabodeta. Punishment diberikan kepada peserta didik untuk menekan karakter negatif dan mengembangkan karakter positif, yang disebut dengan ekstinksi. Proses ekstinksi ini dapat dilakukan dengan cueing (isyarat) terhadap perilaku negatif dan incompatible behavior (penguatan pada perilaku yang sebaliknya). Bentuk punishment disesuaikan dengan tingkat pelanggarannya seperti yang dijelaskan oleh Ormrod (2012: 57-62) yaitu menggunakan scolding (teguran verbal), response cost (biaya respons), logical consequences (konsekuensi logis), time out (diasingkan) dan in-school suspension (skors di sekolah).

Kegiatan penutup merupakan kegiatan yang meliputi diantaranya penilaian dan kegiatan tindak lanjut. Hal ini dijelaskan dalam Peraturan Menteri No. 41 tahun 2007 tentang Standar Proses, bahwa dalam kegiatan penutup terdiri atas guru: a) bersama-sama dengan peserta didik dan/atau sendiri membuat 
rangkuman/simpulan pelajaran; b) melakukan penilaian dan/atau refleksi terhadap kegiatan yang sudah dilaksanakan secara konsisten dan terprogram; c) memberikan umpan balik terhadap proses dan hasil pembelajaran; d) merencanakan kegiatan tindak lanjut dalam bentuk pembelajaran remedial, program pengayaan, layanan konseling dan/atau memberikan tugas baik tugas individual maupun kelompok sesuai dengan hasil belajar peserta didik; menyampaikan rencana pembelajaran pada pertemuan berikutnya. Mulyasa (2012: 212) menjelaskan bahwa kegiatan penilaian dimaksudkan untuk menilai kualitas proses pendidikan karakter dan pembentukan kompetensi peserta didik, termasuk cara-cara tujuan-tujuan belajar direalisasikan. Kegiatan penilaian pembelajaran berkarakter dapat dilakukan secara bertahap dan berkesinambungan yang dilakukan melalui kegiatan proses dan hasil pembelajaran. Ternyata, $74 \%$ guru MI se-Jabodeta telah melaksanakan penilaian secara bertahap dan berkesinambungan baik dari sisi proses ataupun hasil belajar.

Dalam kegiatan penutup, tahapan pembelajaran berbasis karakter terdapat dalam kegiatan tindak lanjut. Kegiatan tindak lanjut merupakan kegiatan untuk menindak lanjuti masalah pembelajaran yang dialami peserta didik. Kegiatan tindak lanjut dilakukan setelah diketahui dari sisi proses dan hasil penilaian pembelajaran berbasis karakter. Tujuan guru melaksanakan kegiatan tindak lanjut adalah memperbaiki proses dan hasil belajar berupa kepemilikan nilai karakter yang diharapkan. Kegiatan tindak lanjut pun menjadi dasar bagi guru untuk menentukan kegiatan remedial, enrichment atau akselerasi terhadap peserta didik. Penentuan tindak lanjut ini dapat dilakukan oleh guru dengan berdiskusi dengan para ahli evaluasi mengenai proses dan hasil pembelajaran. Kegiatan tindak lanjut ini telah dilaksanakan oleh 51\% guru MI di wilayah Jabodeta. Kegiatan tindak lanjut juga bertujuan untuk mengukur ketercapaian program pembelajaran berabasis karakter. Hal ini ditegaskan oleh Mulyasa (2012: 198-199) dengan sejumlah rumusan pertanyaan yaitu; 1) apa yang dikerjakan peserta didik?, 2) jenis dan pola pikir apakah yang digunakan (ingatan, pemahaman, analisis, kritis, evaluatif) peserta didik?, 3) apakah bentuk materi yang dipelajari peserta didik dan guru (fakta, konsep, prosedur, analisis dan teori,)?, 4) tipe pengorganisasian macam apakah yang digunakan oleh guru? 5) bagaimanakah guru dan peserta didik mendeskripsikan iklim dan norma kelas? dan 6) dalam hal apa peserta didik secara khusus dilibatkan?. Diketahui bahwa 70\% guru MI se-Jabodeta menjadikan hasil penilaian sebagai landasan untuk melakukan tindak lanjut dan dalam rangka memperbaiki program pembelajaran dengan tujuan agar pembelajaran berbasis karakter berhasil optimal.

Teknik penilaian pembelajaran berbasis karakter dapat dilakukan dengan menggunakan alat observasi, membuat catatan anekdot dan monitoring bersama antara guru dengan orang tua. Kegiatan observasi dapat dijadikan sebagai teknik penilaian pembelajaran berbasis karakter seperti yang dijelaskan oleh Mulyasa (2012: 206-214) bahwa observasi adalah salah satu teknik penilaian pembelajaran 
berbasis karakter melalui pengumpulan data yang pengisiannya berdasarkan pengamatan langsung terhadap sikap dan perilaku peserta didik. Observasi dapat berbentuk observasi partisipatif, observasi sistematis maupun observasi eksperimental. Berdasarkan hasil penelitian diketahui bahwa 53\% guru MI seJabodeta telah melakukan kegiatan observasi. Tujuan observasi ini untuk memantau kemajuan hasil belajar dalam bentuk kepemilikan sejumlah karakter tertentu atas peserta didik.

\section{Kesulitan Guru MI dalam Pelaksanaan Pembelajaran Berbasis Karakter}

Identifikasi kesulitan pelaksanaan pembelajaran berbasis karakter bertujuan untuk menentukan langkah konstruktif bagi terwujudnya pendidikan karakter yang optimal. Ternyata 51\% guru MI Bogor, 56\% guru MI Jakarta, 49\% guru MI Tangerang dan 50\% guru MI Depok mengalami kesulitan dalam melaksanakan pembelajaran berbasis karakter. Berdasarkan ukuran Skala Likert diperoleh hasil; 2\% guru MI selalu mengalami kesulitan dalam melaksanakan pembelajaran berbasis karakter, 19\% sering kesulitan, 71\% kadang-kadang kesulitan dan 8\% tidak pernah kesulitan. Indikator kesulitan pelaksanaan pembelajaran berbasis karakter meliputi aspek teladan guru, monitoring penanaman karakter, penilaian hasil belajar karakter, metode penanaman karakter, proses integrasi karakter pada mata pelajaran, penyusunan desain karakter, buku panduan dan identifikasi nilai karakter.

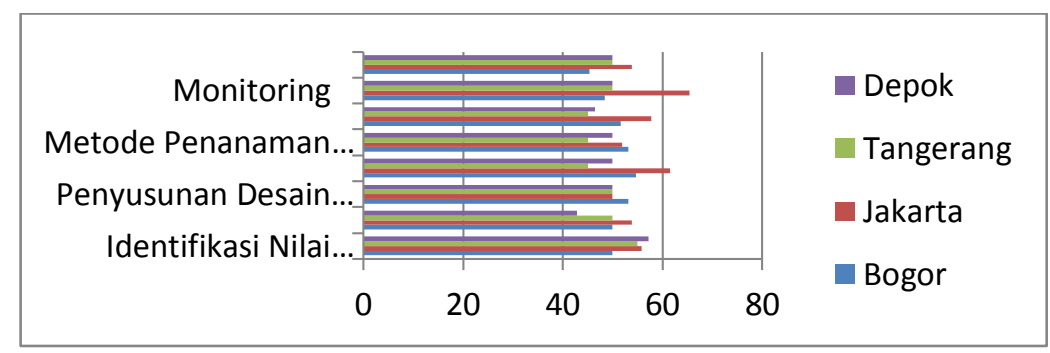

Sebanyak 45\% guru MI untuk wilayah Jakarta, 54\% guru MI untuk wilayah Jakarta, 50\% guru MI untuk wilayah Tangerang dan Depok mengalami kesulitan dalam penanaman nilai karakter melalui pemberian teladan. Aspek keteladanan dalam pembelajaran berbasis karakter merupakan bagian dari upaya pembudayaan. Seperti yang dijelaskan Mulyasa (2011) bahwa pembudayaan dapat terwujud dengan pemodelan, penghargaan, pengidolaan, fasilitasi serta hadiah dan hukuman. Jadi jika guru sulit memberikan keteladanan dalam penanaman karakter maka akan sulit juga bagi peserta didik untuk menginternalisasikan nilai karakter dalam kehidupannya.

Kegiatan monitoring dalam penanaman karakter dimaksudkan sebagai bentuk pengawasan terhadap ketercapaian dan konsistensi tindakan berkarakter bagi peserta didik. Kegiatan ini dirasakan sulit oleh 48\% guru MI dari wilayah Bogor, 65\% guru MI untuk wilayah Jakarta, 50\% untuk wilayah Tangerang dan Depok. Proses monitoring memang membutuhkan kerjasama dari berbagai 
pihak seperti orang tua, guru dan masyarakat yang disebut dalam Panduan Pembangunan Karakter Bangsa (Mulyasa, 2012: 232-235) sebagai tiga pilar pendidikan karakter. Masing-masing pilar pendidikan karakter apabila berlangsung secara harmoni dengan peran masing-masing akan bersinergi dengan keberhasilan proses internalisasi nilai karakter terhadap peserta didik. Misalnya masing-masing pilar mengembangkan proses intervensi dan habituasi dalam penanaman karakter kepada peserta didik. Dalam intervensi dikembangkan suasana interaksi belajar dan pembelajaran yang disengaja dan dirancang untuk mencapai tujuan pembentukan karakter dengan menerapkan kegiatan yang terstruktur. Dalam habituasi sedemikian rupa diciptakan situasi dan kondisi serta penguatan yang memungkinkan peserta didik pada satuan pendidikan, di rumah dan di lingkungan masyarakatnya terbiasa berperilaku yang berkarakter. Proses pemberdayaan dan pembudayaan mencakup pemberian contoh, pembelajaran, pembiasaan dan penguatan yang dilakukan secara sistemik, holistik dan dinamis. Upaya sinergisitas ketiga pilar pendidikan karakter juga ditegaskan oleh Mulyasa (2012: 232-236) bahwa internalisasi karakter harus terjadi dalam empat pilar yaitu kegiatan belajar-mengajar/pembelajaran di kelas, kegiatan keseharian dalam bentuk pengembangan budaya satuan pendidikan, kegiatan ko-kurikuler dan/atau ekstrakurikuler serta kegiatan keseharian di rumah dan di masyarakat.

Pada aspek penilaian (pengukuran) hasil belajar, diperoleh hasil bahwa 52\% Guru MI Bogor, 58\% guru MI Jakarta, 45\% guru MI Tangerang dan 50\% guru MI Depok mengalami kesulitan melakukan praktik penilaian terhadap pelaksanaan pembelajaran berbasis karakter. Penilaian hasil belajar dalam pembelajaran berbasis karakter tidak hanya membutuhkan instrumen penilaian yang berorientasi afektif tetapi juga performa atau tindakan karakter seperti yang dijelaskan oleh Kesuma (2011: 137) bahwa yang dimaksud dengan penilaian berbasis karakter adalah suatu proses untuk menilai kepemilikian suatu suatu karakter oleh anak yang dilakukan secara terencana, sistematis, sistemik dan terarah pada tujuan yang jelas.

Faktor yang menjadi kesulitan guru dalam penerapan pembelajaran berbasis karakter adalah pemilihan metode penanaman karakter. Hasilnya ternyata 53\% guru MI Bogor, 52\% guru MI Jakarta, 45\% guru MI Tangerang dan 50\% guru MI di wilayah Depok mengalami kesulitan dalam memilih metode yang tepat dalam penanaman karakter. Kemampuan guru dalam memilih dan menentukan suatu metode pembelajaran dapat dijadikan standar keberhasilan pencapaian tujuan pembelajaran termasuk penanaman nilai karakter seperti dijelaskan oleh Khan (2010: 18) bahwa metode yang berbeda dengan metode yang lain merupakan a way in achieving something. Kesulitan guru dalam menemukan metode pembelajaran berbasis karakter menjadi indikasi sulitnya penanaman nilai karakter bagi peserta didik tercapai.

Aspek lain yang menambah daftar kesulitan guru dalam pelaksanaan pembelajaran berbasis karakter adalah kegiatan integrasi karakter pada setiap 
mata pelajaran. Ternyata, 55\% guru MI Bogor, 62\% guru MI Jakarta, 45\% guru MI Tangerang dan 50\% guru MI Depok mengalami kesulitan dalam mengintegrasikan nilai karakter terutama untuk mata pelajaran umum. Proses integrasi nilai karakter dalam mata pelajaran merupakan kunci utama bagi terlaksananya pembelajaran berbasis karakter, sehingga apabila mayoritas guru masih kesulitan dalam melakukan integrasi nilai karakter dalam setiap mata pelajaran maka dapat diindikasikan bahwa pelaksanaan pembelajaran berbasis karakter itu sulit diterapkan.

Para guru juga mengalami kesulitan dalam penyusunan desain pembelajaran berbasis karakter. Diketahui bahwa 53\% guru MI Bogor, 50\% guru MI Jakarta, Tangerang dan Depok mengalami kesulitan dalam menyusun desain pelaksanaan pembelajaran berbasis karakter. Sebuah desain pembelajaran pada umumnya, juga termasuk dalam pembelajaran berbasis karakter, melibatkan prosedur penyajian materi ajar dan rencana pelaksanaan pembelajaran sehingga jika guru kesulitan dalam komponen ini sudah pasti mereka kesulitan pula dalam mencapai tujuan utama pembelajaran berbasis karakter yaitu tertanamnya nilai karakter.

Optimalisasi pelaksanaan pembelajaran berbasis karakter dapat dicapai dengan efektif ketika didukung oleh ketersediaan sumber belajar berupa buku panduan pelaksanaan pembelajaran berbasis karakter. Namun sumber belajar pada ketersediaan buku panduan ini ternyata dirasakan sulit ditemukan oleh $50 \%$ guru MI Bogor, 54\% guru MI Jakarta, 50\% guru MI Tangerang dan 43\% guru MI Depok. Kondisi ini tentu saja akan menghambat berhasilan pelaksanaan pembelajaran berbasis karakter karena keberadaan buku panduan pelaksanaan pembelajaran berbasis karakter merupakan salah satu sumber bagi pengembangan kompetensi guru khususnya dalam melaksanaan pembelajaran berbasis karakter.

Aspek lain yang menjadi daftar kesulitan bagi guru dalam melaksanakan pembelajaran berbasis karakter adalah mengidentifikasi nilai karakter pada setiap tujuan pembelajaran dari masing-masing bidang studi. Ternyata, 50\% guru MI Bogor, 56\% guru MI Jakarta, 55\% guru MI Tangerang dan 57\% guru MI Depok mengalami kesulitan untuk melalukan identifikasi nilai-nilai karakter. Proses identifikasi nilai karakter ini penting untuk dirumuskan dalam mendesain pelaksanaan pembelajaran berbasis karakter. Tujuan mengidentifikasi nilai karakter agar dijadikan alat kendali bagi proses pembelajaran lalu diorientasikan pada karakter yang telah ditetapkan namun tetap berhubungan dengan tujuan pembelajaran pada setiap mata pelajaran. Kegiatan ini disebut dengan proses pembelajaran bermakna (meaningfull learning). Jika guru tidak bisa mengidentifikasi nilai karakter dalam setiap pembelajaran khususnya pada bidang studi umum tentu saja cita-cita penanaman nilai karakter pada setiap peserta didik akan sulit diwujudkan. Proses identifikasi nilai karakter dapat mengikuti langkah-langkah yang dikembangkan oleh Mulyasa (2012: 14-15) yaitu menentukan indikator karakter, menjelaskan definisi dari karakter, melakukan elaborasi terhadap 
substansi makna yang terkandung dalam karakter melalui hirarki perilaku seperti hirarki dari T. Lickona menjadi moral knowing, moral feeling dan moral action, atau menggunakan hirarki taksonomi Bloom yaitu kognitif, afektif, dan psikomotor. Menyusun indikator dari karakter tersebut ke dalam bentuk rincian khusus suatu indikator hasil belajar yang harus dikuasai oleh peserta didik hendaknya sesuai dengan tahap perkembangan peserta didik dan penjabarannya didasarkan pada indikator penilaian.

\section{SIMPULAN}

Penelitian ini menunjukkan bahwa mayoritas (87\%) guru MI se-Jabodeta memahami pelaksanaan pembelajaran berbasis karakter. Pada aspek pelaksanaan pembelajaran berbasis karakter yang meliputi penyusunan desain, pemilihan pendekatan dan penilaian pembelajaran berbasis karakter, 71\% guru MI seJabodeta telah melakukan kegiatan yang dibutuhkan dalam perangkat pelaksanaan pembelajaran berbasis karakter. Berdasarkan rating scale yang digunakan, diketahui 33\% selalu dan sering, 25\% kadang-kadang dan 5\% tidak pernah melaksanakan kegiatan pembelajaran berbasis karakter dengan menggunakan perangkat pelaksanaan pembelajaran berbasis karakter seperti desain, penentuan pendekatan dan penilaian pembelajaran yang juga berbasis karakter. Secara keseluruhan, 52\% guru MI se-Jabodeta mengalami kesulitan untuk melaksanakan pembelajaran berbasis karakter. Aspek kesulitan yang dirasakan oleh guru MI se-Jabodeta berkenaan dengan keteladanan, monitoring, pengukuran keberhasilan, metode penanaman karakter, proses integrasi karakter, penyusunan desain pembelajaran, buku panduan dan identifikasi nilai karakter dalam pelaksanaan pembelajaran berbasis karakter.

\section{DAFTAR PUSTAKA}

Depdiknas. 2003. UU RI No 20 Tentang Sistem Pendidikan Nasional,” Jakarta: Departemen Pendididikan Nasional, Direktorat Jendral Pendidikan Luar Sekolah dan Pemuda.

Gunansyah. 2010. Integrasi Pendidikan Nilai dalam Membangun Karakter di Sekolah Dasar. Diakses: www.kompasiana.com

Jamaris, Martini. 2010. Orientasi Baru dalam Psikologi Pendidikan. Jakarta: Yayasan Panamas Murni.

Khan, Yahya. 2010. Pendidikan Karakter Berbasis Potensi Diri. Yogyakarta: Pelangi Publishing.

Koesoema, A., Doni. 2007. Pendidikan Karakter: Strategi Mendidike Anak di Zaman Global. Jakarta: Grasindo.

Kesuma, Dharma, dkk. 2011. Pendidikan Karakter: Kajian Teori dan Praktek di Sekolah. Bandung: Remaja Rosdakarya.

Madjid, Abdul. 2008. Perencanaan Pembelajaran: Mengembangkan Standar Kompetensi Guru. Bandung: PT. Remaja Rosdakarya.

Mulyasa. E. 2012. Manajemen Pendidikan Karakter. Jakarta: PT. Bumi Aksara. 
Ormrod, Jeanne, Ellis. 2012. Human Learning (6th). USA: Pearson Education Inc. Peraturan Menteri Pendidikan Nasional No. 41 Tahun 2007 Tentang Standar Proses.

Siregar, Eveline dan Nara, Hartini. 2010. Teori Belajar dan Pembelajaran. Bogor: PT. Ghalia Indonesia.

Sugiyono. 2012. Metode Penelitian Pendidikan: Pendekatan Kuantitatif, Kualitatif, dan R\&D. Bandung: Alfabeta.

Suyanto. 2009. Urgensi Pendidikan Karakter. Ditjen Mandikdasmen - Kementerian Pendidikan Nasional.

Trianto. 2007. Model Pembelajaran Terpadu: Teori dan Praktek. Jakarta: Prestasi Pustaka Publishing.

www.mapenda.go.id.

Zubaedi. 2011. Desain Pendidikan Karakter: Konsepsi dan Aplikasinya dalam Lembaga Pendidikan. Jakarta: Prenada Media Group. 